\title{
The Effect of Various Learning Approaches on Mathematical Learning Outcomes based on the Multiple Intelligences of Students
}

\author{
By Yerizon Yerizon ${ }^{*} \&$ Atus Amadi Putra
}

\begin{abstract}
The aim of this paper is to describe the research results on multiple intelligences in mathematics learning, using a descriptive approach. It also ascertains the influence of various learning models on mathematics learning outcomes based on students' multiple intelligences. Student Teams-Achievement Divisions (STAD) and Team Games Tournament (TGT) learning models improved learning outcomes for students possessing logical-mathematical, kinesthetic, and interpersonal intelligences. Furthermore, Group Investigation (GI) and Numbered Head Together (NHT) learning models improved student learning outcomes with logical-mathematical intelligence. Two Stay Two Stray (TSTS) learning model with peer tutors improved student learning outcomes with linguistic, logical-mathematical, and interpersonal intelligences. Team Assisted Individualization (TAI) and Jigsaw learning improved student learning outcomes with linguistic intelligence. Also, TSTS and NHT learning models improved student learning outcomes with logical-mathematical, and interpersonal intelligences.
\end{abstract}

Keywords: compound intelligence, learning model, mathematics

\section{Introduction}

There are many students whom experience difficulty while learning mathematics, which makes it difficult to master mathematical concepts. Students experiencing difficulties may lack the initiative to try again and do not ask for help from a teacher. They feel afraid or embarrassed to ask when they do not understand a problem, therefore their learning outcomes are low due to their difficulty (Fadila et al. 2014); for example, calculating the volume and surface area of spaces, solving problems related to circular elements, and the relationship between two circles (Pradana et al. 2014, Sholikhah et al. 2014).

This may be due to the fact that mathematics learning in schools is still teacher-centered and does not pay attention to the multiple intelligences of students (Pradana et al. 2014, Sholikhah et al. 2014, Widyawati et al. 2014, Abidin 2017, Taufik and Adiastuty 2017, Suwanto 2019, Susilo et al. 2018, Laksmiwati and Retnowati 2019). Students have been proven to possess different intelligences. The ones with high visual-spatial intelligence tend to think visually, while the ones possessing verbal intelligence like to read, are good at telling stories, and writing stories or poetry. Students with interpersonal intelligence have good interactions

*Lecturer, Department of Mathematics, Universitas Negeri Padang, Indonesia.

${ }^{ \pm}$Lecturer, Department of Statistics, Universitas Negeri Padang, Indonesia. 
with others, are good at establishing social relationships, and are able to know and apply various methods of interacting (Setiawan and Nisa 2018).

Therefore, during learning, the teacher has to pay attention to the intelligence diversity in their students. The learning of mathematics requires conformity with the theory of multiple intelligences (Amstrong 2009, Susilo et al. 2018). To enhance multiple intelligences in learning, many things can be done, such as choosing models, strategies, approaches, and learning media.

\section{Literature Review}

The multiple intelligence theory was initiated by Howard Gardner from Harvard University, United States. Howard Gardner is a humanistic psychologist professor of education at the Graduate School of Education. In 1983, Gardner wrote a book titled "Frames of Mind: The Theory of Multiple Intelligences" which was published in 1993.

Gardner (1995) defined intelligence as the ability to solve problems and produce results in a variety of settings and real-life situations (Amir 2013, Taufik and Adiastuty 2017). Additionally, Gardner explained intelligence as (1) the ability to solve problems that occur in human life; (2) problem-solving skills which enable a person achieve the goals of a certain objective or situation; (3) the ability to determine the right direction or method towards a target (Riyanto 2010). There are several kinds of intelligence expressed by Gardner (Hamdi 2011, Amir 2013, Sholikhah et al. 2014, Indriani and Hariastuti 2017, Sunendar 2017, Taufik and Adiastuty 2017, Aini et al. 2018, Setiawan and Nisa 2018, Fathani 2019, Kurniawati and Kurniasari 2019, Laksmiwati and Retnowati 2019, Palayukan and Ledon 2019, Suwanto 2019, Nugroho and Husni 2020) namely:

\section{Verbal Intelligence (Linguistic Intelligence)}

This is the ability to use and process words effectively, both orally and in writing. The characteristics of children with prominent linguistic intelligence include writing stories or poetry, reading, telling stories, enjoy learning foreign languages, good vocabulary and spelling, writing letters or e-mail, talking about ideas with friends, a strong ability to remember names or facts, enjoys word games (juggling words, hidden words, scrabble or crossword puzzles, puns or rhymes) and enjoys reading about eye-catching ideas

\section{Logical-Mathematical Intelligence}

This is an ability to solve problems involving numbers and logic effectively. Students with high logical-mathematical intelligence show a great interest in exploration. This intelligence has characteristics, specifically a sensitivity to logical relationship patterns, statements and propositions, logical functions and other abstractions (Khiyarusoleh 2018). A person with high logical mathematical intelligence is usually interested in numbers, science, easily performs math 
mentally, enjoys solving mysteries, likes to count, make predictions, guess numbers (for instance, the number of coins in a container), easily memorizes numbers and scores, enjoys strategy games such as chess, pays attention to actions and consequences (known as cause-and-effect), spends time doing brain teasers or logic puzzles, likes to check out how computers work and organize information into tables or graphs, as well as how they can use a computer more productively, instead of just playing games.

\section{Visual-Spatial Intelligence}

This is the ability to properly capture the visual-space world, such as that of hunters, architects, navigators, and decorators. Students with high visual-spatial intelligence tend to think visually. This intelligence includes sensitivity to colors, lines, shapes, spaces and the relationships between these elements. A spatially intelligent individual usually remembers faces rather than names, likes to draw ideas or make sketches to solve problems, thinks in pictures and easily sees objects mentally. Furthermore, they love to build or construct, enjoys reading, drawing maps, looking at photos/pictures and talk about them, like to see the patterns of the world, doodle, draw in great detail and realistically, remember things learned in form of pictures, observing people performing several activities, solving visual/picture puzzles and optical illusions and builds models or anything in 3dimensions. Students with visual intelligence are usually rich in imagination, which enables their creativity.

\section{Bodily-Kinesthetic Intelligence}

This is the ability to use the body or gestures to express ideas and feelings, similar to that of actors, athletes, dancers, sculptors, and surgeons. Students with above average bodily-kinesthetic intelligence, enjoy moving and touching. They have control, balance, dexterity, and grace in movement, and like to explore the world with their muscles.

\section{Musical Intelligence}

This is the ability to develop, express, and enjoy musical notes and sound forms. Students with prominent musical intelligence easily recognize and remember tones. They can also transform words into songs, and create various musical plays. Additionally, they are good at singing the beat of a song properly, musical vocabulary, and sensitivity to rhythm, melody or sound color in a musical composition.

\section{Interpersonal Intelligence}

This is the ability to understand and be sensitive to other people's feelings, intentions, motivations, dispositions, temperaments. Students with prominent interpersonal intelligence have good interactions with other people, easily establish 
social relationships, and are able to know and utilize various methods of interacting. They are also able to perceive the feelings, thoughts, behavior and expectations of others, and easily cooperate.

\section{Intrapersonal Intelligence}

This is related to self-knowledge and the inherent ability to adapt. Students with prominent intra-personal intelligence have a sense of feeling in ongoing situations, understand themselves, and are able to control themselves during conflict. They also know what can be done and what cannot be done in a social environment. Furthermore, they know the right person to approach when they have to.

\section{Naturalist Intelligence}

This is the ability to understand flora and fauna well. Students with prominent naturalist intelligence have a great interest in the environment, including animals, at a very early age. They enjoy objects and stories related to natural phenomena, for example the occurrence of clouds and rain, origin of animals, plant growth, and the solar system.

\section{Existence Intelligence}

This involves an individual's sensitivity and the ability to answer the deepest problems of human life and existence. Students with such intelligence are curious about human existence, the meaning of life, why humans experience death, and the realities they face. This intelligence was developed by Gardner in 1999.

The benefits of applying multiple intelligence in the learning process of mathematics include (Hamdi 2011, Amir 2013, Pradana et al. 2014, Rofiah 2016, Susilo et al. 2018):

1) Creates student motivation to learning mathematics.

2) Provides various study methods for students according to their interests, and talents.

3) Improves their abilities in their preferred fields.

4) Provides a positive influence in a pleasant learning atmosphere without limiting students.

5) Ability to facilitate students with various types of intelligence (Armstrong 2009).

6) Reduces the tendency of teachers to teach only in accordance with their most prominent types of intelligence.

7) Improve mathematics learning outcomes.

The dimensions of multiple intelligences contained in the 2013 curriculum can be seen in three ways. Firstly, the development of four core competencies (KI), namely spiritual attitudes, social attitudes, knowledge and skills. Secondly, 
the application of a scientific approach which includes: observing, questioning, experimenting, associating, and communicating. Thirdly, the assessment system carried out is in form of authentic assessment (Machali 2014).

\section{Methodology}

This study was carried out to determine various results on multiple intelligences in mathematics learning. The intensive and rigorous literature review was done to analyze the effect of multiple intelligences in mathematics learning. There were two methods that were used to search the relevant and appropriate literature of the research.

At the first phase, several related electronic databases were explored to investigate for the relevant articles, such as: EBSCO host; Elsevier; Science Direct; Emerald; JSTOR; ProQuest; Sage Publications; SciVerse; Scopus; Springer Link; Taylor and Francis Online; and Wiley Online. The main keywords used were: compound intelligence; learning model; mathematics and learning; twenty-first century teaching and learning; the effective teaching and learning in general, and specifically in mathematics subject at primary to higher institution level. Furthermore, each single journal was examined individually to find more pertinent papers, for example, International Electronic Journal of Mathematics Education; Mathematics Education; Eurasia Journal of Mathematics; Science \& Technology Education; Procedia-Social and Behavioral Sciences; Asian Social Science, etc.

At the second phase, the relevant articles were identified based on the pull out bibliography of the crucial articles of the above literature review using the snowballing method. The literature exploration was done from 2019 to 2020 and restricted to only teaching and learning studies available between 2009 and 2019. This leads to the limitation of this study. If it is found that an article fulfilled these two elements: (a) it focused predominantly on multiple intelligences in mathematics learning and learning of mathematics in general and specifically in mathematics subject at all level, (b) the investigation was carried out in the venue of primary to higher institutions and among mathematics educators, then this article will be included in this study. Peer-reviewed articles that were published in academic journals were also included. Furthermore, conference proceedings and theses were also included in this review. Duplication, indistinguishable and identical publications that were deemed irrelevant were removed from the review. Articles were selected for relevance, essentially based on the title, abstracts, and keywords.

\section{Results and Discussion}

The research results on students' multiple intelligences in mathematics learning have been conducted by several researchers (Hamdi 2011, Amir 2013, Fadila et al. 2014, Machali 2014, Pradana et al. 2014, Rohman 2014, Safitri et al. 2014, Sholikhah et al. 2014, Widyawati et al. 2014, Miftachudin et al. 2015, 
Indriani and Hariastuti 2017, Sunendar 2017, Taufik and Adiastuty 2017, Aini et al. 2018, Susilo et al. 2018, Fathani 2019, Kurniawati and Kurniasari 2019, Laksmiwati and Retnowati 2019, Palayukan and Ledon 2019, Suwanto 2019, Nugroho and Husni 2020).

Hamdi (2011) examined the advantages of learning mathematics through CTL, involving multiple intelligences in building student character. There are seven main components of effective learning involved in CTL: constructivism; questioning; inquiry; learning community; modeling; reflection; and authentic assessment. An example of character that was built is honesty. This was observed in the process of proving the formula, which has to undergo a process of honesty and openness. That is, all related aspects will be disclosed openly and thoroughly, including the consequences of such proof. The results showed that multiple intelligence-based CTL was highly suitable for building student character. This was because in the learning process the teacher incorporated the real world into the classroom and encouraged students to make connections between the knowledge they have and its application in everyday life.

In its application, teachers must have more options for choosing the curriculum. This approach must be adapted to the behavior and abilities of the students. Teachers need to choose strategies that can be used effectively to improve creative thinking, critical thinking and parenting skills. Not all terms can be used in a study. Teachers should try to find information that is relevant to the student's life environment.

Amir (2013) conducted an experiment to determine the effects of multiple intelligence-based mathematics learning. The results showed that through paying attention to the multiple intelligences of students, teachers aroused their motivation to learn. This was attainable, because students learned according to their interests, and talents. Therefore, this method improved students' abilities in their preferred fields, as it provided a positive influence in a pleasant learning atmosphere, without limiting students.

Every student is special; they are very different. The Work Experience Index shows that everyone has nine skills. In the classroom, the teacher has to choose from several faces to get the face. It is very difficult to adapt everything in class. The instructor should pack all materials that are relevant to the environment and that are appropriate for the students.

Fadila et al. (2014) conducted a research in class VII SMP to ascertain the effect of the Student Team Outcome Division (STAD) and Team Games Tournament (TGT) cooperative learning models with a contextual approach to learning achievement. It also aimed to determine the effective aspects of multiple intelligence on student mathematics learning. The results showed that: 1) The outcome of students' mathematics learning using the TGT learning model in a contextual approach was better than the STAD learning model; 2) The outcome of students whose learning involved the TGT model with a contextual approach was as good as the STAD model; 3) Student learning outcomes with logicalmathematical intelligence were as good as kinesthetic and interpersonal intelligence. In addition, the learning outcomes with mathematical logical intelligence were better than visual, kinesthetic and interpersonal intelligence. 
The TGT model is better at helping students learn math than the STAD model. In the TGT model, students are motivated to learn about sports. Students enjoy playing with games, however the teacher must be able to manage the activities of this game because it has been demonstrated that many students get distracted by football and forget to study. Students with visual intelligence like this type of learning.

Machali (2014) conducted an experiment to determine the relevance of changes and curriculum development in 2013 to multiple intelligences. The results showed that the 2013 curriculum made room for the development of multiple intelligence dimensions which can be seen in three ways. Firstly, in competency development, which consists of four core competencies (KI), namely spiritual and social attitudes, knowledge, and skills. In the multiple intelligence category, there are dimensions of existential; interpersonal; intrapersonal; linguistic; logicalmathematical; musical; visual/spatial; bodily-kinesthetic; and naturalist/ environmental intelligences. Secondly, the scientific approach is applied, which includes observing, questioning, experimenting, reasoning, associating, and communicating which is very relevant to the development of learning using multiple intelligences. Thirdly, an authentic assessment method is applied, which is also highly relevant.

The 2013 curriculum is designed to fit students' potential through research. Based on step-by-step research, almost all of the students' intellectual potential is affected. However, there are still teachers who have not done their job, due to various challenges such as the support of facilities and the attitude of the teachers themselves.

Pradana et al. (2014) conducted research in class VIII SMP to determine the effect of the NHT-type cooperative learning model using the CTL approach on the subject matter of flat-sided shapes involving students' multiple intelligences. Students possessing the verbal, logical-mathematical, interpersonal, and spatial types of intelligence had the same achievement. This is because during their learning process, they were able to take advantage of their verbal intelligence in understanding each sentence in the given problem. The ones with logicalmathematical intelligence had the advantage in performing calculations in questions. Furthermore, students with interpersonal intelligence were also able to work together, ask questions and discuss with other students. This enabled them to obtain adequate information in order to solve the given problem. In addition, students with spatial intelligence were able to imagine shapes and make pictures that helped to solve problems.

The results of the research include (1) the learning outcome for students that used the NHT-CTL learning model was better than the NHT and direct learning models, while the NHT model was as good as the direct learning model, (2) students possessing verbal, logical-mathematical, interpersonal, and spatial types of intelligence had the same achievement, (3) in each of the multiple intelligences, the learning outcome for students that used the NHT-CTL learning model was better than the NHT and direct learning models, while the NHT model was as good as the direct learning model,(4) in each learning model, the mathematics 
learning outcome for students with verbal, logical-mathematical, interpersonal, and spatial intelligence was equally good.

To improve student math, NHT-CTL curriculum should be determined by students' patience in problem solving. In learning with a NHT curriculum, students need to be more responsible and math-minded and expect to do homework. In math, teachers need to use the NHT-CTL curriculum to become more proficient. The teacher should pay attention to, and understand the characteristics of the students; for example, the various skills that students can learn, such as the language, the study of mathematics, math, and differences.

Safitri et al. (2014) conducted research in class VII SMP to determine the effect of using peer tutoring and independent cooperative learning models with elearning on the subject of algebra involving multiple intelligences. The results are: (1) In groups where students learned using the peer tutoring cooperative learning model, they had better mathematics learning outcomes than students whom used the self-learning model with e-learning and direct learning. In the group where students used the independent learning model alongside e-learning, they had better mathematics learning outcomes than the group taught using the direct learning model. (2) The learning outcome of students having interpersonal intelligence was better than that of students with intrapersonal and linguistic intelligence. Furthermore, the ones with verbal-linguistic intelligence had better mathematics outcome than students with intrapersonal intelligence.

(3) In peer tutoring cooperative learning, the mathematics learning outcome in students with interpersonal intelligence was better than the ones with intrapersonal. Meanwhile, students with intrapersonal and interpersonal intelligence had the same mathematics learning outcome with the ones having verbal intelligence. In independent e-learning, there was no significant difference between the mathematics learning outcome of students having both interpersonal and verbal types. In direct learning, students having intrapersonal and interpersonal types had the same mathematics learning outcome. Furthermore, the interpersonally intelligent students had the same mathematics learning outcome as the ones having verbal, while students having verbal had a better learning outcome than the ones with intrapersonal intelligence.

For the time being during COVID-19, we had to develop e-learning, and there are many times when this course is completed online. Learning partnerships need to be reduced because we need to control the distance to prevent the spread of the virus. If you want to get involved, you also have to go online.

Sholikhah et al. (2014) conducted an experiment in class VIII SMP to ascertain the effect of Group Investigation (GI) and Numbered Heads Together (NHT) cooperative learning models on material tangents to circles involving students' multiple intelligences. The results showed that: (1) The mathematics learning outcome for students whom used the NHT learning model was better than GI and direct learning, while that of students whom used the GI learning model was better than the direct model (Santoso 2010). (2) The mathematics learning outcome for students having logical-mathematical intelligence was better than in individuals with interpersonal and linguistic, while that of students with interpersonal intelligence was the same as verbal intelligence. (3) In the NHT 
learning model, the mathematics learning outcome for students having logicalmathematical, interpersonal, and linguistic intelligence were the same.

As a result of this course, the teacher should be able to focus on the diversity of the various skills that are common among the students, including math, social studies, social skills, and intelligence. Many skills affect student achievement. For classes conducted by students with critical thinking, math and / or individual skills, the NHT and GI curriculum can be used as an alternative to learning decisions. For classes where students are proficient in speaking, the NHT learning model can be used as an alternative to new academic activities.

Widyawati et al. (2014) conducted research in class VII SMP using rectangular flat shapes to determine the effect of the Two Stay Two Stray (TSTS) and Numbered Heads Together (NHT) learning models involving multiple intelligences of students. The conclusions obtained are: (1) the TSTS cooperative learning model produced better mathematics learning outcomes than the NHT and direct learning model, while the NHT cooperative learning model produced better outcomes than the direct; (2) The mathematics learning outcome of students having logical-mathematical intelligence was better than the ones with interpersonal and verbal. Furthermore, the learning outcome of students having interpersonal was better than verbal; (3) For students having logical-mathematical intelligence, the TSTS cooperative learning model produced better learning outcomes than the NHT, while the TSTS and NHT cooperative learning models produced the same learning outcome as the direct learning model. For students having interpersonal intelligence, the TSTS-type cooperative learning model produced the same learning outcome as the NHT and the direct, while the NHT-type cooperative learning model produced better mathematics learning outcomes than the direct model. For students having linguistic intelligence, the cooperative learning model TSTS, NHT, and direct learning models produced the same mathematics learning achievement; (4) In the TSTS cooperative learning model, the learning outcome of students having interpersonal intelligence was the same as logical-mathematical, and verbal intelligence. Furthermore, the learning outcome of students having logical-mathematical intelligence was better than the ones with verbal intelligence. In the NHT type of cooperative learning model, the learning outcome of students having logical-mathematical, interpersonal and verbal intelligence was the same. In the direct learning model, the learning outcome of students having logicalmathematical intelligence was better than interpersonal and linguistic intelligence. In addition, the learning outcome of students having interpersonal intelligence was the same in students having verbal intelligence.

Miftachudin et al. (2015) conducted research in class VII SMP to determine the effectiveness of the TSTS type learning model with peer tutors in learning mathematics on a flat shape material which involves multiple intelligences. From the results, the following were observed: (1) The TSTS learning model with peer tutors resulted in better student outcomes compared to the direct. (2) Students with logical-mathematical, verbal and interpersonal intelligences had the same achievement. (3) In the TSTS learning model with peer tutors, students with logical-mathematical, verbal and interpersonal intelligence had the same student achievement. (4) Students with logical-mathematical intelligence, verbal and 
interpersonal intelligence produced better learning achievements compared to the direct learning models.

This type of learning will be susceptible to transmission of the COVID-19 virus. It should be done online, but there will be many obstacles in its implementation. We can use a variety of applications suitable for this type of learning.

Taufik and Adiastuty (2017) conducted a research in class VIII MTs to describe relations and functions in mathematics learning involving multiple intelligences, using a scientific approach. The steps involved 1) preliminary activities; 2) core activities which include observing, asking questions, gathering information, associating and communicating; and 3) conclusion and evaluation. The multiple intelligences involved include verbal/linguistic, visual/spatial, logical/mathematical, musical, bodily/kinesthetic, interpersonal, and intrapersonal. This research is a classroom action research with two cycles in which each cycle consists of four phases. They are planning, action, observation and reflection. Results of each cycle were analyzed on two types; the first type on students and teacher activities and the second type on students learning outcome. The results can be seen in Table 1 and Table 2.

Table 1. Analyses on Students and Teacher Activities on the Cycles

\begin{tabular}{|l|c|c|c|}
\hline Cycle & Activity & Average (\%) & Category \\
\hline I & Students' Activities & 70 & Poor \\
\hline & Teacher' Activities & 76 & Enough \\
\hline II & Students' Activities & 82 & Good \\
\hline & Teacher' Activities & 83 & Good \\
\hline
\end{tabular}

Table 2. Analysis on Students Learning Outcome who Exceed the Passing Grade 75\% Correct Answers on the Cycles

\begin{tabular}{|l|c|c|}
\hline Cycle & Number of Students & Percentage \\
\hline I & 18 & 46 \\
\hline II & 31 & 80 \\
\hline
\end{tabular}

Therefore, the increase in learning outcome from cycle I to II was $34 \%$. In research, there are several factors that are key to the success of an actionable research finding. First, researchers and educators form different groups. Mixing students with multiple levels of ability will increase resources in a group. Second, researchers reduce teacher education, by providing a broader way for students to analyze, ask questions, explore data from a variety of disciplines, participate, and present work and give presentation groups.

Third, researchers and educators provide students with a variety of ways to solve questions with more complex levels by asking and doing homework, so that students have sufficient knowledge and experience in the use of certain terms. Fourth, researchers and educators provide support to students. Diligence is the key that is required by educators in an effort to improve learning. Creating support for students can do two things: provide support and encouragement. 
Aini et al. (2018) conducted an experiment in class VIII SMP to describe students' mathematical literacy in solving math questions about number pattern problems which involved multiple intelligence. The results showed that students with verbal-linguistic intelligence, logical-mathematical and naturalists have the same tendency to identify concepts, define and determine initial ideas, find relationships between variables, and make mathematical models of problems. However, the indicators used to describe a mathematical situation were different for each intelligence. Verbal-linguistic and logical-mathematical students can write down situations using symbols, but naturalist students cannot. Furthermore, in designing strategies, students having verbal intelligence tend to write down steps with easy-to-understand delivery. Logical-mathematical students formulated steps that produced the right solution, while naturalist students tend to use pictures.

Kurniawati and Kurniasari (2019) conducted a research in class X SMA to describe the mathematical literacy of students with verbal, logical-mathematical and spatial intelligences in solving PISA problems involving space and shape content. The results showed that students with verbal intelligence underwent several processes, namely identifying mathematical aspects of the problem, translating problems into mathematical language, designing strategies to determine solutions (but not entirely accurate), describing the steps for solving problems according to the strategies designed, reinterpreting the results or solutions into the context of real-world problems, and explaining the reasons for the accuracy of the given conclusions. Students with logical-mathematical-intelligence underwent several processes, namely, identifying mathematical aspects of the problem, translating them into mathematical language, designing strategies to determine solutions, describing the steps for determining mathematical solutions in detail, and systematically not reinterpreting the results or solutions obtained into the context of real-world problems, but clarifying the appropriateness of the given conclusion. In addition, subjects with spatial intelligence underwent several processes, namely, identifying mathematical aspects of the problem, translating them into mathematical language, designing strategies to determine solutions, and not reinterpreting the results obtained in the context of real-world problems, but clarifying the appropriateness of the given conclusion.

There should be a set of criteria for research prior to the data retrieval collection process that has been carried out with the aim of correcting the sentences in the research so that they can be well-understood by the research with no misrepresentation. In the math test questions, the researcher should write down the information for each subject to write a conclusion on a given problem or translate the math solution into more applicable meanings of everyday life. Because there are some studies that do not write a conclusion, it is better if the researcher informs the decision to write down the final conclusion of the problemsolving process. In order for these results to be widespread, relevant studies should be carried out so that it can explain students' mathematical literation in solving PISA questions on others topics.

Nugroho and Husni (2020) conducted research in class VIII SMP to determine the learning outcome in the TAI and Jigsaw cooperative learning model involving multiple intelligences. The results showed that: (1) there was a 
significant difference in learning outcomes in this cooperative learning model before and after treatment; (2) there was no significant difference in outcome between students having linguistic, logical mathematical, and other types; (3) there was no significant difference in outcome between linguistic, logical-mathematical and others in the implementation of the TAI type learning model; (4) there was no significant difference in learning outcome between students having verbal, logicalmathematical and other intelligences in the implementation of the Jigsaw type learning model; (5) there was a positive, significant difference in learning outcome between the TAI and Jigsaw learning models in students with verbal intelligence.

Students achieve a wide range of multidisciplinary skills including language skills, mathematical skills and other skills. This shows that all types of intelligence of students have similarities in problem solving. This is based on the discovery of a collaborative study of the TAI and Jigsaw modes where there is no difference in the achievement of the same type of learning among the more intelligent students.

The potential of the skills acquired by the students must be considered by the instructor in the field of mathematics in order to develop effectively. Curriculum can be customized according to local circumstances and the abilities of the students.

TAI co-curricular activities enable students to assist in the design of instruction for peer-to-peer learning, so that the learning of students with good language skills can be improved and their math skills improved as well.

\section{Conclusions}

From the research results, the following conclusions were obtained:

1. Students with verbal intelligence are suitable for peer tutoring and independent learning models with e-learning, Two Stay Two Stray with peer tutors, TAI and Jigsaw.

2. Students with logical-mathematical intelligence are suitable for the STAD and TGT, GI and NHT learning models, Two Stay Two Stray with peer tutors, TSTS and NHT.

3. Students with kinesthetic intelligence are suitable for the STAD and TGT learning models,

4. Students with interpersonal intelligence are suitable for the STAD and TGT learning models, peer tutoring and independent e-learning, Two Stay Two Stray with peer tutors, TSTS and NHT able should be editable and must be at an appropriate place in the main text such as figures. For the tables, use the following format.

\section{Acknowledgments}

This research was supported by Universitas Negeri Padang in accordance with the research contract number 1546/UN35.13/LT/2020, fiscal year 2020. 


\section{References}

Abidin Z (2017) Pengembangan Kecerdasan Majemuk di Madrasah (Development of multiple intelligences in Madrasah). Elementary: Jurnal Ilmiah Pendidikan Dasar 3(2): 120-131.

Aini NR, Suharto S, Yudianto E, Trapsilasiwi D, Setiawan TB (2018) Analisis Berpikir Literasi Matematika Siswa dalam Menyelesaikan Soal Matematika pada Pokok Bahasan Pola Bilangan Berdasarkan Kecerdasan Majemuk (Analysis of student's matematical literacy thinking in solving mathematics problems on pattern of number based on multiple intelligences). Kadikma 9(2): 127-135.

Amir A (2013) Pembelajaran Matematika dengan Menggunakan Kecerdasan Majemuk (Learning mathematics using multiple intelligences). Logaritma 1(1): 1-14.

Amstrong T (2009) Multiple intelligence in the classroom. $3^{\text {rd }}$ Edition. Alexandria: ASCD. Fadila A, Budiyono, Riyadi (2014) Eksperimentasi Model Pembelajaran Kooperatif Tipe STAD dan TGT dengan Pendekatan Kontekstual terhadap Prestasi Belajar dan Aspek Afektif Matematika Siswa Ditinjau dari Kecerdasan Majemuk (Experimentation of cooperative learning model type STAD and TGT with a contextual approach to learning achievement and affective aspects of student mathematic in terms of multiple intelligences). Jurnal Elektronik Pembelajaran Matematika 2(1): 1-14.

Fathani AH (2019) Pembelajaran Matematika bagi Santri Pondok Pesantren Berbasis Kecerdasan Majemuk (Learning mathematics for Santri of Islamic boarding schools based on multiple intelligences). ANARGYA: Jurnal Ilmiah Pendidikan Matematika 2(1): 49-55.

Gardner H (1995) Reflection on multiple intelligences: myths and messages. Phi Delta Kappan 77(3): 200-209.

Hamdi S (2011) Membangun Karakter Siswa dalam Pembelajaran Matematika Melalui CTL Berbasis Kecerdasan Majemuk (Building student character in mathematics learning through multiple intelligences based on CTL). In Seminar Nasional Matematika dan Pendidikan Matematika FMIPA UNY, 488-498.

Indriani E, Hariastuti RM (2017) Profil Pemahaman Matematis Siswa SMPN 1 Tegaldlimo ditinjau dari Kecerdasan Majemuk (Profile of mathematical understanding of 1 junior high school students of Tegaldlimo in terms of multiple intelligences). TRANSFORMASI-Jurnal Pendidikan Matematika \& Matematika 1(2): $1-11$.

Khiyarusoleh U (2018) Kecerdasan Logika-Matematika Dilihat dari Kecerdasan Majemuk Siswa SMA di Brebes Selatan (Logical-mathematical intelligence seen from the multiple intelligences of senior high school students in South Brebes). Naturalistic: Jurnal Kajian Penelitian Pendidikan dan Pembelajaran 3(1): 240-246.

Kurniawati I, Kurniasari I (2019) Literasi Matematika Siswa dalam Menyelesaikan Soal PISA Konten Space and Shape Ditinjau dari Kecerdasan Majemuk (Students' mathematical literacy in solving PISA problems on space and shape content in terms of multiple intelligences). MATHEdunesa, Jurnal Ilmiah Pendidikan Matematika, 8(2): 441-448.

Laksmiwati PA, Retnowati E (2019) Pengembangan Perangkat Pembelajaran Geometri Berbasis Kecerdasan Majemuk Siswa SMP kelas VIII (Development of geometry learning tools based on multiple intelligences for VIII class junior high school students). PYTHAGORAS: Jurnal Pendidikan Matematika 14(1): 1-11.

Machali I (2014) Dimensi Kecerdasan Majemuk dalam Kurikulum 2013 (Dimensions of multiple intelligences in the 2013 curriculum). Insania 19(1): 21-45. 
Miftachudin, Budiyono, Riyadi (2015) Efektivitas Model Pembelajaran Two Stay Two Stray dengan Tutor Sebaya dalam Pembelajaran Matematika pada Materi Bangun Datar Ditinjau dari Kecerdasan Majemuk Peserta Didik Kelas VII SMP Negeri di Kebumen Tahun Pelajaran 2013/2014 (The effectiveness of the two stay two stray learning model with peer tutors in mathematics learning on flat-building topic in terms of multiple intelligences of VII class junior high school students in Kebumen, 2013/2014 academic year). Jurnal Elektronik Pembelajaran Matematika 3(3): 233241.

Nugroho AG, Husni M (2020) Prestasi Belajar Siswa dalam Pembelajaran Kooperatif Tipe TAI dan Jigsaw Ditinjau dari Kecerdasan Majemuk (Student achievement in cooperative learning type TAI and Jigsaw in terms of multiple intelligences). Media Pendidikan Matematika 8(1): 42-50.

Palayukan H, Ledon M (2019) Pengembangan Perangkat Pembelajaran Matematika Berbasis Kecerdasan Majemuk untuk Siswa SMA (Development of mathematics learning tools based on multiple intelligences for senior high school students). Seminar Nasional FST 2(Jan): 175-184.

Pradana LN, Atmojo T, Usodo B (2014) Eksperimentasi Model Pembelajaran Kooperatif Tipe Numbered Heads Together dengan Pendekatan Contextual Teaching and Learning pada Materi Pokok Bangun Ruang Sisi Datar Ditinjau dari Kecerdasan Majemuk Siswa SMP Negeri Kelas VIII se-Kota Madiun (Experimentation of the cooperative learning model type numbered heads together with a contextual teaching and learning approach on constructing flat-sided spaces topic in terms of multiple intelligences of VIII Class junior high school students in Madiun). Jurnal Elektronik Pembelajaran Matematika 2(10): 1031-1041.

Riyanto Y (2010) Paradigma Baru Pembelajaran (New paradigm of learning). Kencana.

Rofiah NH (2016) Menerapkan Multiple Intelligences dalam Pembelajaran di Sekolah Dasar (Implementing multiple intelligences in learning in elementary schools). Jurnal Dinamika Pendidikan Dasar 8(1): 69-79.

Rohman N (2014) Eksperimentasi Model Pembelajaran Cooperative Learning (CL) dan Group Investigation (GI) Ditinjau dari Kecerdasan Majemuk Siswa (Experimentation of cooperative learning (CL) model and group investigation (GI) in term of student's multiple intelligence). Jurnal Edutama 1(1): 17-21.

Safitri DN, Kusmayadi TA, Usodo B (2014) Eksperimentasi Model Pembelajaran Kooperatif Peer Tutoring dan Mandiri dengan E-learning pada Pokok Bahasan Aljabar Ditinjau dari Kecerdasan Majemuk (Experimentation of cooperative learning type peer tutoring and independent with e-learning on algebra subject in terms of multiple intelligences). Jurnal Elektronik Pembelajaran Matematika 2(1): 99-109.

Santoso FGI (2010) Efektivitas Pembelajaran Berbasis Masalah dan Pembelajaran Kooperatif Bertipe Group Investigation Terhadap Prestasi Belajar Matematika Ditinjau dari Kecerdasan Majemuk Siswa Kelas VII SMP Negeri Kota Madiun (The effectiveness of problem based learning and cooperative learning type group investigation on mathematics learning achievement in terms of multiple intelligences of VII class junior high students in Madiun). Tesis Tidak Diterbitkan. Surakarta: PPs UNS.

Setiawan D, Nisa K (2018) Kajian Kecerdasan Majemuk pada Beberapa Model Pembelajaran Kooperatif (Study of multiple intelligences in several cooperative learning models). In Semdikjar-2, 215-222.

Sholikhah OH, Budiyono, Saputro DRS (2014) Eksperimentasi Model Pembelajaran Kooperatif Tipe Group Investigation (GI) dan Numbered Heads Together (NHT) pada Materi Garis Singgung Lingkaran Ditinjau dari Kecerdasan Majemuk Siswa Kelas VIII SMP Negeri se-Kota Madiun Tahun Ajaran 2013/2014 (Experimentation 
of group investigation (GI) and cooperative learning model type numbered heads together (NHT) on circular tangent topic in term of multiple intelligences of VIII class junior high school in Madiun, 2013/2014 academic year). Jurnal Elektronik Pembelajaran Matematika 2(7): 727-739.

Sunendar A (2017) Perangkat Pembelajaran Matematika Berbasis Teori Kecerdasan Majemuk Apa dan Bagaimana Mengembangkannya (Mathematics learning tools based on the theory of multiple intelligences and how to develop it). Jurnal THEOREMS (The Original Research of Mathematics) 1(2): 1-12.

Susilo TAB, Reza MD, Fachrudin AD, Widadah S, Kohar AW (2018) Pembelajaran Matematika Realistik yang Melibatkan Kecerdasan Majemuk pada Materi Volume Bangun dan Luas Permukaan untuk Sekolah Dasar (Realistic mathematics learning involving multiple intelligences on volume and surface area topic for elementary schools). Jurnal Edukasi 4(2): 99-121.

Suwanto S (2019) Penerapan Pembelajaran Kooperatif Berbasis Multiple Intelligence di Sekolah Menengah Pertama pada Materi Kubus dan Balok (Application of cooperative learning based on multiple intelligence in junior high schools on cube and cuboid topic). In Prosiding Seminar Nasional \& Expo II Hasil Penelitian dan Pengabdian Masyarakat, 1621-1628.

Taufik A, Adiastuty N (2017) Penerapan Pembelajaran Matematika yang Melibatkan Kecerdasan Majemuk dengan Pendekatan Saintifik (Application of mathematics learning involving multiple intelligences with a scientific approach). JES-MAT 3(1): 45-60.

Widyawati S, Mardiyana M, Iswahyudi G (2014) Eksperimentasi Model Pembelajaran Kooperatif Tipe Two Stay Two Stray (TSTS) dan Numbered Heads Together (NHT) Ditinjau dari Kecerdasan Majemuk Peserta Didik (Experimentation of cooperative learning models type two stay two stray (TSTS) and numbered heads together (NHT) in terms of the student's multiple intelligences). Jurnal Elektronik Pembelajaran Matematika 2(9): 972-983. 
